Are there Institutional Differences in the Earnings of Australian Higher Education

Graduates? $^{1}$

Paul Koshy, National Centre for Student Equity in Higher Education, Curtin University, GPO Box U1987 Perth Western Australia 6845; e-mail: p.koshy@curtin.edu.au (Corresponding author)

Richard Seymour, Bankwest Curtin Economics Centre, Curtin University, GPO Box U1987 Perth Western Australia 6845; e-mail: r.seymour@curtin.edu.au

Mike Dockery, National Centre for Student Equity in Higher Education, Curtin University, GPO Box U1987 Perth Western Australia 6845; e-mail: m.dockery@curtin.edu.au

(Published in Economic Analysis and Policy, Volume 51, September 2016, Pages 1-11)

\footnotetext{
${ }^{1}$ This paper reflects in part comments on an earlier, unpublished version of this paper. The authors would like to acknowledge two independent referees and journal editor for their comments.
} 


\title{
Are there Institutional Differences in the Earnings of Australian Higher Education Graduates? ${ }^{1}$
}

\begin{abstract}
This paper examines the effect of university quality, as proxied by institutional groupings, on the earnings outcomes of Australian university qualified persons. It uses data from the Household, Income and Labour Dynamics in Australia (HILDA) survey to examine the impact of a variety of factors on earnings, including: institution grouping, gender, age, field of study and industry of employment.

The paper reports strong evidence for large and significant field of study and industry effects on the earnings of university graduates. There is no significant evidence for the existence of an institutional effect in Australia, save for a minor effect in relation to regional universities. However, splitting the sample along gender lines reveals some evidence for negative earnings premiums for females in universities outside the Group of Eight and Australian Technology Network, with no such observed effects among males. Overall, the findings indicate a relatively muted earnings effect across Australian university groupings.
\end{abstract}

\section{Introduction}

The central premise of the human capital model is that increased levels of education are associated with increased skill accumulation and productivity, leading to higher earnings for individuals. The benefits of higher earnings are in turn often coupled with other documented benefits such as better health outcomes, increased longevity and improved marriage and parenting prospects (Clarke and Leigh, 2011; Hartog and Oosterbeek, 1998). It is this general acceptance of the human capital model and the calculated benefits of education which underpins much of the rationale for public funding of education and how that funding is allocated.

Thus the level of earnings (and implied returns) from increasing rates of participation in, and perceived quality of, education are an important question for policymakers, not only in terms of the broader question of widening participation, but also in relation to questions of resourcing and planning. In higher education, where graduates enjoy the highest earnings premia, there are a number of issues of particular interest, including the extent to which gender and choice of academic discipline affect graduate outcomes.

In addition to these considerations, there is speculation that university quality, or perceptions of university quality, may impact on earnings and so this may be another factor

\footnotetext{
${ }^{1}$ This paper reflects in part comments on an earlier, unpublished version of this paper. The authors would like to acknowledge two independent referees and a journal editor for those comments.
} 
driving earning differentials. There is an increasing body of empirical work examining the influence of university type and ranking on post-graduation salary outcomes. This issue is of particular relevance to Australian higher education, not only because of the stratification in the system in terms of measures of institutional quality but also in terms of the role various institutions play in enabling access to higher education. This paper reports estimates of a wage equation for a sample of Australian university graduates drawn from the Household, Income and Labour Dynamics in Australia (HILDA) survey. Specifically, it reports on the extent to which graduate earnings are impacted upon by the type of university attended after allowing for a wide variety of control variables.

\section{The Estimation of Returns to Education and Institutional Effects}

The relationship between education and earnings, as predicted in the human capital model, is typically estimated using the wage equation attributed to Mincer (1974). A standard specification of the model takes the following form:

$$
\operatorname{Ln}\left(y_{i}\right)=\beta_{0}+\beta_{1} e d u c_{i}+\beta_{2} \exp _{i}+\beta_{3} \exp _{i}^{2}+\beta_{n} Z_{n i}+\varepsilon,
$$

where $\operatorname{Ln}(y)$ is the natural logarithm of income (usually measured either weekly or hourly), educ is the number of years of education, and $\exp$ and $\exp ^{2}$ denote labour market experience and its square respectively, while $Z$ is a vector of other explanatory variables, such as age, location and field of study. In this specification, increasing levels of education are expected to be positively associated with income $\left(\beta_{1}>0\right)$, while earnings over the course of a person's working lifetime are expected to increase with years of experience $\left(\beta_{2}>0\right)$ but at increasingly smaller increments due to diminishing returns to experience $\left(\beta_{3}<0\right)$. In effect, education is assumed to be positively correlated with skill acquisition and, combined with experience, commands an earnings premium in the labour force. In this model, human capital accumulation - through education and labour market experience - is the primary determinant of differentials in income levels between individuals. This standard model has been estimated in various forms and elements encompassed in the $Z$ vector.

A review of the development of human capital theory and empirical work in Australia appears in Preston (1997). She confirms that Australian studies support the existence of an earnings premium for university graduates and more experienced workers (at diminishing rates over time) and lower premia for female workers and those individuals with younger children. Borland et al (2000) suggest that studies conducted over the 1980s and 1990s in Australia 'tend to find similar results' along the lines of a 10 to $15 \%$ return to a Bachelor's degree compared to high school education only and thus 'it seems reasonable to conclude that the private return to a university degree is fairly sizeable' (p. 15).

In terms of the calculation of rates of return to human capital accumulation, two recent estimations of the human capital model in Australia have provided evidence on historical 
trends and contemporary returns. ${ }^{2}$ Wei (2010) examines Australian Bureau of Statistics (ABS) Census data from 1981 to 2006, and finds that the measured rate of return increased at each census to 2001 , where it peaked at $19.3 \%$, before falling to $15.3 \%$ in 2006 . The rate of return for females also peaked in 2001 , at $19 \%$, declining to $17.8 \%$ in 2006 . However, Wei finds that these results are driven by improved employment outcomes among those without degrees, and that on an 'employees only' basis the returns to undergraduate degrees increase over time' (p.11). Daly and Lewis (2010) confirm Wei's results for the decline in the rate of return to a university undergraduate degree between 1986 and 2006, using ABS Census data in a study examining returns in three fields of study: Economics, Law, and Business.

Studies in human capital also focus on the relative benefits of the level of education (if any) in instances of over- or under-education, where individuals enter occupations with average levels of education which are above or below the required level of educational attainment for the occupation (see Dockery and Miller 2012 for an examination of this question in the Australian context). Australian and international studies consistently find a positive return to required years of education for the job, but a lower return for years of education in excess to that required. The research also finds that persons who manage to secure jobs for which they are under-educated enjoy a wage premium. An important aspect of this approach is that it incorporates both the demand and supply side of the labour market, while wages equations often consider only the supply side (the individual's attributes). The empirical evidence makes it clear that the demand side matters.

Another important area of research that incorporates demand side factors has been the relative returns of graduates given their level of qualification (e.g. School Leavers, Undergraduate Degrees, Postgraduate Coursework Degrees, etc.) and from different fields of study (e.g. Engineering; Law; Education). The Daly and Lewis (2010) study finds that bachelor degree holders have consistently enjoyed a wage premium over school leavers, peaking at 1.98 times that of school leaver earnings in 2001, somewhat declining to 1.64 times school leaver earnings in 2006 (p. 354). Despite this finding, the earnings differential for undergraduate degree holders is still substantial. Preston (1997) finds evidence over the first part of this period (late 1980s to mid-1990s) of substantial discrepancies across fields of study in Australia, with higher returns for Engineering, Law and Business, relative to Education, Arts and Nursing.

\footnotetext{
${ }^{2}$ There are two main approaches to estimating individual 'returns' to education. One is to estimate the wage premium associated with further years of education; the other is to calculate a 'rate of return' or net present value of the expected increase in life-time earnings relative to the costs, which include foregone earnings while in education and direct tuition costs. In this paper we focus on the former of these approaches, the wage premium. Studies of the rate of return, such as Wei (2010), demonstrate that differences are largely driven by differences in employment propensity as well as wage differences. The fall in the return to a degree, as noted in this paragraph, largely reflected employment gains to non-degree holders during the period of Wei's 2010 study.
} 


\section{Institutional Effects}

In view of the above evidence institutional effects on graduate earnings could be important in higher education. This is because universities tend to draw students of similar academic and socio-economic backgrounds for most of their courses. This commonly reflects the history of higher education, where historic institutions developed to cater to a relatively small enrolment, followed by an expansion in both overall enrolment and the number of institutions (Marginson, 2011; Koshy, 2016).

Australia is somewhat unique in having a higher education system which is both academically stratified and geographically segregated. In 2014, 85.5 per cent of all applicants in 2014 applied to an institution in their home state or territory, with inter-state applications largely confined to nationally competitive courses, such as Medicine which accounted for 20.5 per cent of all inter-state applicants (Australian Government Department of Education 2015). This organisation reflects the growth of Australia's higher education infrastructure whereby the first six universities were funded by state governments, based in state capital cities, and received students from state-controlled secondary systems. The arrival of new institutions in post-war Australia, although often promulgated through policy by the Commonwealth such as the 'Dawkins' reforms' of the 1980s, constituted additions to institutions in state and territory jurisdictions, creating a local hierarchy in higher education.

This history is still in effect today. Over the last two decades, the advent of shared goals and challenges among institutions across the country has seen the creation of four recognised institutional groupings among Australia's 38 major universities, with 12 institutions remaining unaligned. The institutional groupings are as follows (Koshy 2016):

- Group of Eight: Australia's older, research intensive universities, who are prominent in globally rankings: Australian National University (ANU), Melbourne, Monash, Sydney, New South Wales (UNSW), Queensland (UQ), Western Australia (UWA), and Adelaide.

- Australian Technology Network (ATN): Newer universities which were formed out of existing institutes of technology in the 1980s: Curtin University, University of Technology, Sydney (UTS), RMIT University (RMIT), Queensland University of Technology (QUT), and University of South Australia (UniSA).

- Innovative Research Universities (IRU): Universities established in the 1960s and 1970s: Murdoch, Flinders, Griffith, James Cook (JCU), Newcastle, La Trobe, and Charles Darwin University (CDU); and

- Regional Universities Network (RUN): New universities with campuses in regional areas: Southern Cross, New England (UNE), Federation, Sunshine Coast (SCU), Central Queensland (CQU), and Southern Queensland (USQ).

Further, there are 12 institutions who are 'unaligned' universities: Macquarie, Wollongong, Deakin, Charles Sturt (CSU), Tasmania, Australian Catholic University (ACU), Canberra, Edith 
Cowan University (ECU), Swinburne, Victoria, Western Sydney (UWS) and The Batchelor Institute (Batchelor), the latter managing its undergraduate courses through CDU in recent years.

There is strong evidence to support the idea that Australia's universities are, as a consequence, stratified in relation to perceived quality. This was recently noted by Norton (2014) in his discussion linking higher education fee setting for international students in Australia to minimum Australian Tertiary Admission Rank (ATAR) entry scores for domestic students.

This perception is in part reflected in the measured level of social disadvantage of students, which can be expected to in turn contribute to employment and earnings outcomes. Indeed, there are large disparities between the institutional groupings in terms of educational disadvantage. Koshy and Seymour (2015) show that in 2014, students from low socioeconomic status backgrounds - those students residing in the bottom $25 \%$ of the Australian population in a postcode ranking of the ABS's SEIFA (Socio-Economic Index for Areas) Index - accounted for $17.9 \%$ of all Australian domestic undergraduates. However, their share in the Group of Eight was around $11 \%$ of enrolments, compared to $16.4 \%$ in the ATN, $21.7 \%$ in the IRU and $29.8 \%$ in RUN.

Given these marked differences, any observed differences in earnings across institutions after allowing for the usual set of controls in human capital models (described above and in the methodology below) will in part reflect the extent to which student socio-economic status impacts on future earnings.

Recent studies in Australia and overseas have looked at returns in relation to institutional differences. Birch, Li and Miller (2009) examine data from the 2003 Graduate Destination Survey (GDS) in Australia to determine if there are institutional differences, as measured by institutional wage premiums, in the returns to educational attainment. They find that while 'field of study' was a moderately important driver of differences in earnings across graduates (accounting for around $12 \%$ of the difference), institution, as measured by institutional groupings (the Group of Eight; the Australian Technology Network), appeared to have minimal impact on graduate salaries, measured in either weekly or hourly terms.

Carroll (2014) uses data from the 2012 GDS and information on global rankings to determine if institutional specific effects exist in determining graduate starting salaries. He finds evidence for a small institutional effect among globally ranked universities which is significant and is separate from selection effects.

In a study of immigrant earnings, Tani, Heaton and Chan (2013) find that immigrants with bachelor qualifications from institutions in Australia and New Zealand, the United Kingdom (UK) and Ireland, the United States (US) and Canada, and sub-Saharan Africa (South Africa), enjoy an earnings premium compared to graduates from other regions, with individuals 
possessing higher degrees from institutions in the UK and US enjoying a wage premium over those with similar qualifications from other countries, including Australia and New Zealand.

Overseas studies have provided some indication of how earnings may differ across institutional types. Brewer, Eide and Ehrenberg (1999) examine rates of variation in US earnings, using data to determine the effect for US universities and smaller colleges. They find a substantial premium for smaller elite colleges, relative to middle and lower ranked public universities, with the evidence on a premium for larger, elite universities being weaker. A recent study of UK data by Walker and Zhou (2013) finds that there is no evidence to suggest any significant difference in returns to education across different types of higher education institution, once background factors are included in the model.

Other studies in the US by Dale and Krueger (2002) and Black and Smith (2006) examine the notion of institutional quality in the context of measurement. Both find that quality is likely to be difficult to capture using a single measure, which in the US context is usually the median score on the Scholastic Aptitude Test (SAT) among an institution's students. For this reason alone, institutional effects will likely be at least partially subsumed where institutions are offering a broadly similar array of offerings. Against this, Black and Smith (2006) observe that the SAT score indicator is the most reliable indicator of college quality, with institutions ordered hierarchically on the basis of the SAT averages of their entrant classes.

The above work has implications for this study. It is likely that given the structure of Australian higher education, with predominantly larger, public funded universities, that the findings for the Australian system as a whole will largely reflect those seen in these two studies of public institutions, with little variation across institutions in comparison with differences in earnings across field of study. This observation and the perception of quality differences across institutional groupings suggest that any differences between Australian institutions in terms of their graduate earnings will manifest themselves in a comparison of earnings across institutional groupings rather than a diverse distribution of earnings premia in a cross-section of individual institutions. 


\section{Data and Methodology}

The data used in this paper is drawn from Waves 1-12 of the Household, Income and Labour Dynamics in Australia (HILDA) Survey. The HILDA Survey commenced in 2001 (Wave 1), with 7,682 households and 19,914 individuals. A further 2,153 households and 5,477 individuals were added to Wave 11 . The survey collects information about economic and subjective well-being, labour market dynamics and family dynamics. Interviews are conducted annually with all adult members of each household. One further question which was added to Wave 12 of the HILDA Survey was on which Australian university an individual obtained their highest post-school qualification from.

In this study we estimate a wage equation which explains variations in university graduate earnings across institutions, with particular reference to the effect of institutional groupings ("Institution Attended"). Given this, the sample used in the empirical analysis only includes those individuals who completed a bachelor degree, honours bachelor degree, graduate degree, graduate certificate, master degree or doctorate at an Australian university who work either full-time or part-time in one or more periods. Due to the limited number of observations in respect to particular universities, and the discussion above on university groupings, the universities were grouped into five broad institutional categories outlined in Appendix B. Four of the categories reflect institutional self-selection into an established category, with the fifth, "Unaligned Institutions" capturing other institutions in the system.

After controlling for missing data, the final unbalanced sample used in the empirical analysis contained 8,789 observations for 1,649 individuals.

The empirical model was used to investigate the notion that institutional quality may impact on earnings outcomes. The dependent variable in the model is the log of the real hourly wage rate for an individual's main job. It is derived from on an individual's gross weekly wage divided by the number of hours per week usually worked in their main job. Table 1 below outlines the variable structure of the model, where the independent variables in the model are presented in terms of the variable class (in bold) and the list of dummy categories for each variable class. The default or omitted category, where applicable, is enclosed in brackets (e.g. "Undergraduate Degree" is the omitted category for "Level of Education"). The variables in the models are primarily binary dummy variables ( 1 or 0$)$. The calculated means of the variables included in the model can be found in Appendix A.

The empirical analysis below presents a wage equation including the standard human capital variables of age, gender, level of education, and experience, along with the key variables of interest "Institution Attended" and "Major Field of Study" (see Table 1). Other controls are included for sector of employment, part-time work status, state and territory, region of employment and industry of employment. 
[Insert Table 1 here]

The preferred model was estimated using the random effects ordinary least squares (OLS) regression specification. The fixed effects specification could not be used as the key variables of interest, "Institution Attended" and "Major Field of Study," are not time-varying for the individual's highest qualification. To mitigate biased estimation due to the possible correlation between the explanatory variables $X_{i}$ and unobserved individual effects $a_{i}$, Mundlak's (1978) formulation was applied to the model. Mundlak suggests that the $E\left(a_{i} \mid X_{i}\right)$ can be approximated as a simple linear function:

$$
a_{i}=\overline{\boldsymbol{x}_{i}} \boldsymbol{a}+\varepsilon_{i}, \quad \varepsilon_{i} \sim N\left(0, \sigma_{\varepsilon}^{2}\right)
$$

As the dependent variable is the log of real hourly wage, the coefficients on binary variables can be interpreted as a percentage changes in the dependent variable relative to the omitted variable.

\section{4. $\quad$ Results}

Table 2 below presents the results of the analysis. As "Undergraduate Degree" is the excluded category for "Level of Education", all results refer to this group and the relevant excluded category pertaining to the parameter estimate. For instance, the model reports a negative effect for female undergraduate graduates. The parameter estimate of -0.03 suggests that females earn around $3 \%$ less than males after controlling for all other effects. Surprisingly, this effect is not statistically significant, perhaps due to the presence of an extensive series of control variables (e.g. variables for the age of children in a family). The model does show a positive wage premium of $6.2 \%$ for married people. Results for the group of "Age" variables reflect the parabola-shape of the lifetime earnings function for most people, with earnings rising with age through to middle age followed by a flattening thereafter, as reflected in the negative parameter on the "Age Squared" variable. The only significant effect for educational attainment is on the "Graduate Diploma or Certificate", variable which carries with it a substantial negative premium of $7.9 \%$ compared to individuals with only an "Undergraduate Degree."

[Insert Table 2 here] 
Of the four variables used to capture occupation-related experience, the linear measures of "Years with Current Employer" (0.6\%) and "Years in Occupation" (1.0\%) are positive and significant at the $1 \%$ and $5 \%$ levels respectively, while their squared counterparts report no effect.

A strong part-time work effect of around $14.1 \%$ is observed ("Work Part-Time", 0.141 , at the $1 \%$ level of significance) on hourly wages, as are regional effects which are negative (e.g. "Outer Regional or Remote Area", -0.072, at the $10 \%$ level) in comparison with metropolitan areas. The "State" effects show mostly negative impacts on hourly earnings across Australia in comparison with New South Wales, with the exception of the two territories (although these results are not significant at the $5 \%$ level).

The model controls for "Major Field of Study" effects using "Education" as the omitted field. Several disciplines, including "Law", "Engineering", "Nursing" and "Medicine" see earnings premia above "Education" at the $1 \%$ or $5 \%$ level of significance. These results are not only significant in the statistical sense, but reveal very large differences in earnings across fields of study. The direct interpretation of the coefficients is that those who completed their highest qualification in "Medicine" earn 50.8\% more than a graduate from "Education"; while the premium associate with "Engineering" is 35.2\%, "Nursing" around $22.8 \%$ and "Law", a premium close to $19.3 \%$.

The "Industry of Employment" variables include significant positive effects for "Finance" $(0.175$ at $1 \%)$ and "Mining" $(0.145$ at $10 \%)$ in comparison to "Education and Training," the omitted control. "Retail Trade" (-0.225 at 1\%) and "Arts and Recreation Services" (-0.212 at $1 \%)$ tended to reduce hourly earnings compared to the control.

Finally, the model incorporates a series of dummy variables for "Institution Attended", as proxied by Australia's broad university groupings and a grouping for unaligned universities. We find little evidence for a significant difference across these groupings relative to the omitted grouping, "Group of Eight" - which represents Australia's older, more established universities. The exception is "Regional University Network" - the RUN universities - whose graduates earn around $11.3 \%$ less than other university graduates $(-0.113$ at the $5 \%$ level).

From this, it would appear that "Field of Study" effects tend to dominate institutional grouping effects in terms of the distribution of earnings outcomes for Australian graduates, after controlling for a wide range of factors. The one exception to this rule, the negative effect associated with graduating from a RUN institution, could be attributable to their (regional) campus location and also the relatively high number of low socio-economic students enrolled at these institutions. Overall, the finding on institutional effects corresponds to other recent work in both Australia and overseas which finds evidence for a limited earnings premium associated with university attended. 
While we control for gender differences in the main model, splitting the sample along gender lines and re-estimating the model without the "Female" variable, and using gender sub-samples provides evidence for differences in "Main Field of Study" and "Institution Attended" between genders.

Both genders have positive earnings impacts as a result of marriage $(0.027$ in the female sub-sample compared to 0.044 in the male sub-sample). However, the effect is only statistically significant in the male data. Noticeable differences include a less pronounced arc in the influence of age on earnings - the parameter on the "Age" variable was significant at the $1 \%$ level for both, but was double the size in the male sub-sample -0.108 compared to 0.05 in the female sub-sample. The female sub-sample also shows a positive and significant earnings premium for doctoral degree holders ("Doctorate") of $11.8 \%$ compared to those with only undergraduate degrees, in comparison with a negative $24.2 \%$ income premium in the male sub-sample.

The returns to "Experience" and "Work Part-Time" in hourly wages were broadly similar in both sub-samples, with no statistically significant effect seen for employment in the public sector (or alternatively, the private sector). The male sub-sample had a significant and negative (-0.185) effect on salary for living in "Outer Regional and Remote Areas" which may reflect the inclusion of industry controls in the model (e.g. "Mining") as well as recently emerging work patterns such as fly-in/fly-out arrangements where workers commute from metropolitan regions to rural and remote worksites.

In terms of "Major Field of Study", discipline-specific effects were seen in both sub-samples, with disciplines such as "Engineering" (0.341 for females; 0.498 for males), "Nursing" (0.193 for females; 0.354 for males), and "Management" (0.090 for females; 0.321 for males), while "Law" was significant at the $5 \%$ level in the female sub-sample only (0.244) and "Information Technology" in the male sub-sample only (0.436).

Finally, splitting the original sample across genders shows considerable differences in the importance of "Institution Attended" on earnings, relative to the control for "Group of Eight." In the males sub-sample, "Institution Attended" carried no statistical importance in the model, relative to the control group. However, in the female sub-sample, attending institutions in the "Regional University Network" saw a reduction in hourly earnings of $19.0 \%$ (-0.190), a result significant at the $5 \%$ level. As well as this, attending an institution in the "Innovative Research Universities" and "Unaligned Universities" groups saw earning declines of $10.3 \%$ and $8.2 \%$ respectively, although the measured effect was not as statistically as strong. These results suggest that institutional differences in earnings seen in the combined sample relate primarily to female graduates. 


\section{Conclusion}

This paper uses data from the HILDA survey to examine the impact of a variety of factors on university graduate earnings, including institutional factors. This analysis is undertaken using the standard wage equation, with the inclusion of other variables, including a control for higher education institution attended.

The key finding from the results for the entire sample is that an observed field of study effect tends to dominate that attributable to institutional grouping ("Institution Attended") in terms of the distribution of earnings outcomes for Australian graduates. The one exception to this rule is for graduates of RUN institutions, who see lower earnings than other graduates, although even this is weakly significant and could be easily attributable to an imprecise measure of the impact on wages of employment in the regions and omitted factors such as size of the employing organisation. However, the general finding corresponds to other recent work in both Australia and overseas which sees limited evidence for an earnings premium associated with university attended.

An analysis of hourly earnings by gender indicates that the lower earnings observed for graduates from RUN institutions is only significant in the female sub-sample, with a reduced earnings (at a lower level of significance) also seen among female graduates from institutions in the "Unaligned Universities" and "Innovative Research Universities." Given this, the overall finding on university effects suggest that institutional differences are relatively muted and may be attributable to regional location and therefore participation in regional labour markets or the unobserved family backgrounds of HILDA participants, which in turn may drive outcomes at the higher education level. To the extent these factors are determining wage differentials across institutional groups it does appear that there is evidence to suggest that institutional effects are limited, with field of study impacts predominating.

Although consistent with existing the Australian and international literature which points to limited institutional wage effects, the lack of evidence of a wage premium attached to graduation from the Group of Eight universities in Australia is still somewhat surprising. This is because there are reasons to expect a positive wage premium for graduates from these more prestigious institutions even if all institutions offered the much the same quality of education. First, because the Group of Eight are widely recognised as being the more prestigious institutions and are therefore likely to attract higher quality entrants. Since we do not have controls for tertiary entrance scores or other measures of previous academic performance, one would expect the results for the Group of Eight to be affected by unobserved factors that might be positively associated with wage outcomes due to this effect. Second, employers' recognition of institutional status would be expected to give graduates from the Group of Eight at least some edge in applying for jobs as graduates. 
A further possibility is that both these effects have diminished over time due to some form of convergence in the reputations of Australian higher education institutions, perhaps through the movement of newer institutions into traditional course offerings such as Medicine and Law, which account for a significant share of the wage differentials seen between graduates. If this is the case, and on the evidence of comparable returns across institutions seen here, it suggests that there is limited scope for price differentiation in degree programs across Australia in similar fields of study, except perhaps where particular programs have outstanding national or international reputations. 


\section{References}

Australian Government Department of Education (2015) Australian Higher Education Statistics, Student Data, various years, 10 June 2015, at https://education.gov.au/student$\underline{\text { data }}$

Birch, E., Li, I. and Miller, P. (2009) 'The influences of institution attended and field of study on graduates' starting salaries', Australian Economic Review, Vol. 42, No. 1, pp. 42-63.

Black, D. and Smith, J. (2006) 'Estimating the returns to college quality with multiple proxies for quality', Journal of Labor Economics, Vol. 24, pp. 701-28.

Borland, J., Dawkins, P., Johnson, D. and Williams, R. (2000) 'Returns to Investment in Higher Education', The Melbourne Economics of Higher Education Research Program Report No. 1, Report to the Vice Chancellor, The University of Melbourne, Melbourne: Melbourne Institute of Applied Economics and Social Research, The University of Melbourne.

Brewer, D., Eide, E. and Ehrenberg, R. (1999) 'Does It Pay to Attend an Elite Private College? Cross-Cohort Evidence on the Effects of College Type on Earnings,' Journal of Human Resources, Vol. 34, No. 1, (Winter), pp. 104-123.

Carroll, D. (2014) 'An Investigation of the Relationship Between University Rankings and Graduate Starting Wages,' Journal of Institutional Research , Vol. 19, No. 1, pp. 46-53.

Clarke, P., and Leigh, A. (2011) 'Death, dollars and degrees: socio-economic status and longevity in Australia', Economic Papers, Vol. 30, No. 3, pp. 348-355.

Dale, S. and Krueger, A. (2002) 'Estimating the payoff to attending a more selective college: An application of the selection on observables and unobservables.' Quarterly Journal of Economics, Vol. 117, No. 4, pp. 1491-1528.

Daly, A. and Lewis, P. (2010) "The Private Rate of Return to an Economics Degree in Australia; an update", Economic Papers, Vol. 29, No. 3, pp. 353-364.

Dockery, A.M. and Miller, P. (2012) Over-education, under-education and credentialism in the Australian labour market, National Centre for Vocational Education and Research ( NCVER) Monograph Series, Adelaide: NCVER.

Hartog, J. and Oosterbeek, H. (1998), 'Health, wealth and happiness: Why pursue a higher education?', Economics of Education Review, Vol.17, No.3, pp.245-56. 
Koshy, P. (2016) Twenty-Five Years of Measuring Disadvantage in Australian Higher Education“, Paper Presented at the European Access Network Conference, Dublin, 31 May2 June.

Koshy, P. and Seymour, R. (2015). Student Equity Performance in Australian Higher Education: 2007 to 2014. National Centre for Student Equity in Higher Education (NCSEHE), Perth: Curtin University.

Marginson, S. (2011) Equity, status and freedom: a note on higher education, Cambridge Journal of Education, Vol. 41, Issue 1, (March), pp. 23-36.

Mincer, J. (1974) Schooling, Experience and Earnings, New York: National Bureau of Economic Research.

Mundlak, Y. (1978), 'On the Pooling of Time Series and Cross Section Data', Econometrica, Vol.46, No.1, pp.69-85.

Preston, A. (1997) 'Where are we now with human capital theory in Australia?' Economic Record, Vol. 73, No. 110, (March), pp. 51-78.

Tani, M., Heaton, C. and Chan, G. (2013) 'The Wage Premium of Foreign Education: New Evidence from Australia,' Australian Economic Review, Vol. 46, No. 4, pp. 395 - 404.

Walker, I. and Zhu, Y. (2013) The Impact of University Degrees on the Lifecycle Earnings: Some Further Analysis, BIS Research Paper No. 112, A report prepared for the Department of Business, Innovation and Skills (BIS), BIS: London.

Wei, H. (2010) Measuring economic returns to post-school education in Australia, Research Paper cat. No. 1351.0.55.032 , Australian Bureau of Statistics. 
Appendix A: Means of the Independent Variables in the Human Capital Model

\begin{tabular}{|c|c|}
\hline Variable & Mean \\
\hline \multicolumn{2}{|l|}{ Personal Characteristics } \\
\hline Female & $53.08 \%$ \\
\hline Female with Children [Female * Dependent Children 5 to 14$]^{3}$ & $15.16 \%$ \\
\hline Female * Dependent Children 0 to 4 & $9.25 \%$ \\
\hline Female * Dependent Children 15 to 24 & $9.49 \%$ \\
\hline Female * Dependent Children $>24$ & $0.55 \%$ \\
\hline Married & $72.09 \%$ \\
\hline Disabled & $13.68 \%$ \\
\hline $\mathrm{Age}^{4}$ & 40.69 \\
\hline Age Squared ${ }^{4}$ & N/A \\
\hline Level of Education [Undergraduate degree] & $62.97 \%$ \\
\hline Doctorate & $4.83 \%$ \\
\hline Master's Degree & $18.56 \%$ \\
\hline Graduate Diploma or Certificate & $13.64 \%$ \\
\hline \multicolumn{2}{|l|}{ Experience } \\
\hline Years with Current Employer ${ }^{4}$ & 7.55 \\
\hline Years with Current Employer Squared ${ }^{4}$ & N/A \\
\hline Years in Occupation ${ }^{4}$ & 9.61 \\
\hline Years in Occupation Squared ${ }^{4}$ & N/A \\
\hline \multicolumn{2}{|l|}{ Labour Force Proportions and Averages } \\
\hline Proportion of time in work ${ }^{4}$ & $87.33 \%$ \\
\hline Female proportion of time in work ${ }^{4}$ & $45.02 \%$ \\
\hline \multicolumn{2}{|l|}{ Employment Characteristics [Full-time; Private Sector] } \\
\hline Public Sector & $43.77 \%$ \\
\hline Work Part-time & $22.76 \%$ \\
\hline Region [Major Capital City] & $76.99 \%$ \\
\hline Inner Regional Area & $16.68 \%$ \\
\hline Outer Regional or Remote Area & $6.33 \%$ \\
\hline
\end{tabular}

${ }^{3}$ [Omitted category in brackets]

${ }^{4}$ Continuous variable. The remainder of the variables are dummy variables. 
Appendix A: (cont'd) Means of the Independent Variables in the Human Capital Model

\begin{tabular}{|c|c|}
\hline Variable & Mean \\
\hline State [New South Wales] & $32.19 \%$ \\
\hline Victoria & $28.44 \%$ \\
\hline Queensland & $17.95 \%$ \\
\hline South Australia & $6.22 \%$ \\
\hline Western Australia & $7.17 \%$ \\
\hline Tasmania & $2.78 \%$ \\
\hline Northern Territory & $1.04 \%$ \\
\hline Australian Capital Territory & $4.21 \%$ \\
\hline Major Field of Study [Education] & $18.81 \%$ \\
\hline Science & $7.21 \%$ \\
\hline Information Technology & $5.47 \%$ \\
\hline Engineering & $6.88 \%$ \\
\hline Architecture & $1.91 \%$ \\
\hline Agriculture & $2.37 \%$ \\
\hline Medicine & $1.59 \%$ \\
\hline Nursing & $5.34 \%$ \\
\hline Other Health & $7.02 \%$ \\
\hline Management & $20.95 \%$ \\
\hline Law & $2.87 \%$ \\
\hline Society and Culture & $15.58 \%$ \\
\hline Hospitality & $0.35 \%$ \\
\hline Arts & $3.65 \%$ \\
\hline Industry of Employment [Education and Training] & $25.21 \%$ \\
\hline Agriculture Industry & $0.77 \%$ \\
\hline Mining & $0.88 \%$ \\
\hline Manufacturing & $4.54 \%$ \\
\hline Utilities & $0.69 \%$ \\
\hline Construction & $2.00 \%$ \\
\hline Wholesale Trade & $2.31 \%$ \\
\hline Retail Trade & $3.05 \%$ \\
\hline Hospitality Industry & $0.86 \%$ \\
\hline Transport & $1.39 \%$ \\
\hline Information Media & $3.23 \%$ \\
\hline Finance & $5.48 \%$ \\
\hline Real Estate & $0.64 \%$ \\
\hline Professional & $15.78 \%$ \\
\hline Administration & $13.56 \%$ \\
\hline Health & $16.46 \%$ \\
\hline Arts and Recreation Services & $1.90 \%$ \\
\hline Other Services & $1.23 \%$ \\
\hline
\end{tabular}


Appendix A: (cont'd) Means of the Independent Variables in the Human Capital Model

\begin{tabular}{lr}
\hline Variable & Mean \\
\hline \hline Institution Attended [Group of Eight] & $33.09 \%$ \\
Australian Technology Group & $16.78 \%$ \\
Innovation Research Universities & $12.38 \%$ \\
Unaligned Universities & $30.16 \%$ \\
Regional University Network & $7.59 \%$ \\
\hline
\end{tabular}




\title{
Appendix B: "Institution Attended": Institutional Groupings of Australian Universities
}

\section{Group of Eight}

Monash University

The Australian National University

The University of Adelaide

The University of Melbourne

The University of Queensland

The University of Sydney

The University of Western Australia

University of New South Wales

Innovative Research Universities (IRU)

Charles Darwin University

Flinders University of South Australia

Griffith University

James Cook University

La Trobe University

Murdoch University

University of Newcastle*
Australian Technology Network (ATN)

Curtin University of Technology

Queensland University of Technology

RMIT University

University of South Australia

University of Technology, Sydney

Regional Universities Network (RUN)

Central Queensland University

Southern Cross University

University of Ballarat

University of New England

University of Southern Queensland

University of the Sunshine Coast

\author{
Unaligned Universities \\ Australian Catholic University \\ Batchelor Institute of Indigenous Tertiary \\ Education \\ Charles Sturt University \\ Deakin University \\ Edith Cowan University \\ Macquarie University \\ Swinburne University of Technology \\ University of Canberra \\ University of Tasmania \\ University of Western Sydney \\ University of Wollongong \\ Victoria University
}

Note: Newcastle left the IRU Group in December 2014. 
Tables in text

Table 1

Human Capital Model Estimations to Explain Log (Real Hourly Wages)

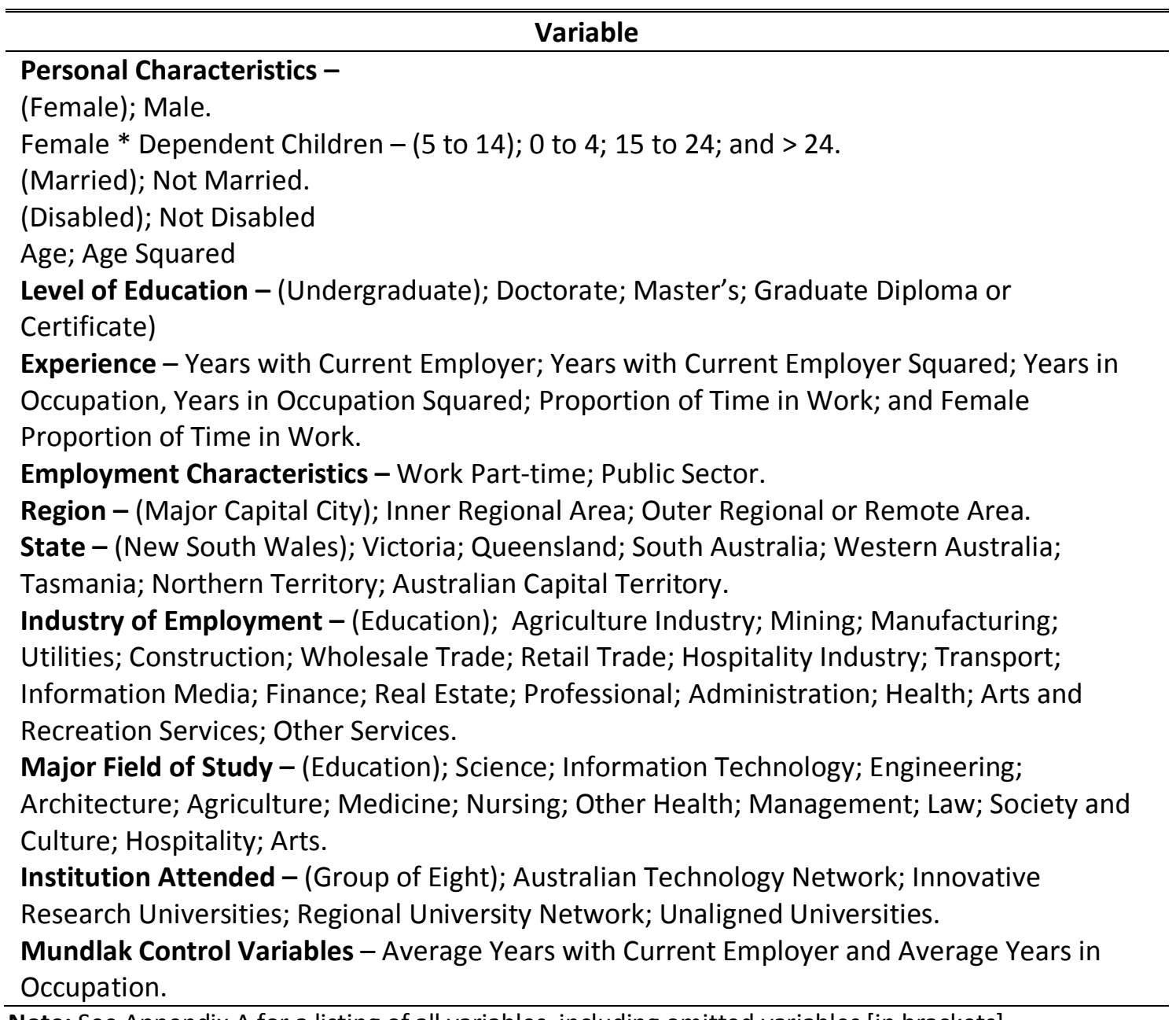

Note: See Appendix A for a listing of all variables, including omitted variables [in brackets]. 
Table 2 Human Capital Model Estimations to Explain Log (Hourly Wages)

\begin{tabular}{|c|c|c|c|}
\hline Variable & Full Model & Females Only & Males Only \\
\hline \multicolumn{4}{|l|}{ Personal Characteristics } \\
\hline Female & $\begin{array}{c}-0.030 \\
(0.125)\end{array}$ & - & - \\
\hline \multicolumn{4}{|c|}{ Female with Children [Female * Dependent Children 5 to 14 ] } \\
\hline Female * Dependent Children 0 to 4 & $\begin{array}{c}0.043 \\
(0.031)\end{array}$ & $\begin{array}{l}0.055^{*} \\
(0.031)\end{array}$ & $\begin{array}{l}-0.022 \\
(0.022)\end{array}$ \\
\hline Female * Dependent Children 15 to 24 & $\begin{array}{c}0.008 \\
(0.025)\end{array}$ & $\begin{array}{r}0.029 \\
(0.027)\end{array}$ & $\begin{array}{l}-0.023 \\
(0.029)\end{array}$ \\
\hline Female * Dependent Children $>24$ & $\begin{array}{c}0.064 \\
(0.063)\end{array}$ & $\begin{array}{c}0.077 \\
(0.064)\end{array}$ & $\begin{array}{c}0.117 \\
(0.083)\end{array}$ \\
\hline Married & $\begin{array}{c}0.062^{*} \\
(0.021)\end{array}$ & $\begin{array}{r}0.027 \\
(0.027)\end{array}$ & $\begin{array}{c}0.044^{* *} \\
(0.032)\end{array}$ \\
\hline Disabled & $\begin{array}{l}-0.009 \\
(0.017)\end{array}$ & $\begin{array}{c}0.005 \\
(0.023)\end{array}$ & $\begin{array}{l}-0.022 \\
(0.023)\end{array}$ \\
\hline \multicolumn{4}{|l|}{ Age } \\
\hline Age & $\begin{array}{l}0.073 * * * \\
(0.008)\end{array}$ & $\begin{array}{l}0.050 * * * \\
(0.010)\end{array}$ & $\begin{array}{l}0.108 * * * \\
(0.013)\end{array}$ \\
\hline Age Squared & $\begin{array}{c}-0.0005^{* * *} \\
(0.000)\end{array}$ & $\begin{array}{l}-0.000 * * \\
(0.000)\end{array}$ & $\begin{array}{l}-0.001 * * * \\
(0.000)\end{array}$ \\
\hline \multicolumn{4}{|l|}{ Level of Education [Undergraduate Degree] } \\
\hline Doctorate & $\begin{array}{l}-0.059 \\
(0.062)\end{array}$ & $\begin{array}{c}0.118^{*} \\
(0.064)\end{array}$ & $\begin{array}{c}-0.242 * * * \\
(0.103)\end{array}$ \\
\hline Master's Degree & $\begin{array}{c}0.005 \\
(0.031)\end{array}$ & $\begin{array}{c}0.053 \\
(0.038)\end{array}$ & $\begin{array}{l}-0.063 \\
(0.052)\end{array}$ \\
\hline Graduate Diploma or Certificate & $\begin{array}{c}-0.079 * * \\
(0.037)\end{array}$ & $\begin{array}{l}-0.015 \\
(0.040)\end{array}$ & $\begin{array}{l}-0.170 * * * \\
(0.000)\end{array}$ \\
\hline Experience & & & \\
\hline Years with Current Employer & $\begin{array}{c}0.006 * \\
(0.003)\end{array}$ & $\begin{array}{l}0.009 * * \\
(0.004)\end{array}$ & $\begin{array}{r}0.004 \\
(0.004)\end{array}$ \\
\hline Years with Current Employer Squared & $\begin{array}{c}0.000 \\
(0.000)\end{array}$ & $\begin{array}{l}-0.000 \\
(0.000)\end{array}$ & $\begin{array}{c}0.000 \\
(0.000)\end{array}$ \\
\hline Years in Occupation & $\begin{array}{l}0.010 * * * \\
(0.002)\end{array}$ & $\begin{array}{l}0.010 * * * \\
(0.003)\end{array}$ & $\begin{array}{l}0.008 * * * \\
(0.003)\end{array}$ \\
\hline Years in Occupation Squared & $\begin{array}{l}-0.000 \\
(0.000)\end{array}$ & $\begin{array}{l}-0.000 \\
(0.000)\end{array}$ & $\begin{array}{l}-0.000 \\
(0.000)\end{array}$ \\
\hline Labour Force Proportions and Averages & & & \\
\hline Proportion in Work & $\begin{array}{l}0.768^{* * *} \\
(0.109)\end{array}$ & $\begin{array}{l}0.690 * * * \\
(0.089)\end{array}$ & $\begin{array}{c}0.670 * * * \\
(0.000)\end{array}$ \\
\hline Female Proportion in Work & -0.031 & & \\
\hline Mundlak Control Variables & $(0.140)$ & & \\
\hline Average Years Current Employer & $\begin{array}{l}-0.015 * * * \\
(0.003)\end{array}$ & $\begin{array}{l}0.013 * * * \\
(0.004)\end{array}$ & $\begin{array}{c}-0.019 * * * \\
(0.004)\end{array}$ \\
\hline Average Occupational Experience & $\begin{array}{c}-0.030 * * * \\
(0.002) \\
\end{array}$ & $\begin{array}{c}-0.026 * * * \\
(0.003)\end{array}$ & $\begin{array}{l}-0.033 \\
(0.004)\end{array}$ \\
\hline
\end{tabular}


Table 2 (cont'd) Human Capital Model Estimations to Explain Log (Hourly Wages)

\begin{tabular}{|c|c|c|c|}
\hline Variable & Full Model & Females Only & Males Only \\
\hline \multicolumn{4}{|c|}{ Employment Characteristics [Full-time; Private Sector] } \\
\hline \multirow[t]{2}{*}{ Work Part-Time } & $0.141^{* * *}$ & $0.141^{* * *}$ & $0.161^{* * *}$ \\
\hline & $(0.020)$ & $(0.022)$ & $(0.045)$ \\
\hline \multirow[t]{2}{*}{ Public Sector } & 0.015 & 0.016 & 0.002 \\
\hline & $(0.021)$ & $(0.026)$ & $(0.033)$ \\
\hline \multicolumn{4}{|l|}{ Region [Major Capital City] } \\
\hline \multirow[t]{2}{*}{ Inner Regional Area } & $-0.074^{* *}$ & -0.054 & $-0.092^{*}$ \\
\hline & $(0.033)$ & (0.039) & $(0.054)$ \\
\hline \multirow[t]{2}{*}{ Outer Regional or Remote Area } & $-0.072^{*}$ & 0.005 & $-0.185^{* * *}$ \\
\hline & $(0.037)$ & $(0.046)$ & $(0.057)$ \\
\hline \multicolumn{4}{|l|}{ State [New South Wales] } \\
\hline \multirow[t]{2}{*}{ Victoria } & $-0.071 * * *$ & $-0.086 * * *$ & $-0.080^{*}$ \\
\hline & $(0.028)$ & $(0.033)$ & $(0.046)$ \\
\hline \multirow[t]{2}{*}{ Queensland } & $-0.066 * *$ & $-0.089 * *$ & -0.030 \\
\hline & $(0.032)$ & $(0.042)$ & $(0.045)$ \\
\hline \multirow[t]{2}{*}{ South Australia } & $-0.165 * * *$ & $-0.117^{* *}$ & $-0.025 * * *$ \\
\hline & $(0.048)$ & $(0.054)$ & $(0.045)$ \\
\hline \multirow[t]{2}{*}{ Western Australia } & -0.023 & 0.015 & -0.094 \\
\hline & $(0.042)$ & (0.049) & $(0.076)$ \\
\hline \multirow[t]{2}{*}{ Tasmania } & -0.099 & $-0.197^{* *}$ & 0.019 \\
\hline & $(0.067)$ & $(0.085)$ & $(0.098)$ \\
\hline \multirow[t]{2}{*}{ Northern Territory } & 0.123 & 0.015 & $0.265^{* *}$ \\
\hline & (0.089) & $(0.108)$ & $(0.131)$ \\
\hline \multirow[t]{2}{*}{ Australian Capital Territory } & 0.067 & 0.051 & 0.076 \\
\hline & $(0.042)$ & $(0.055)$ & $(0.067)$ \\
\hline \multicolumn{4}{|l|}{ Major Field of Study [Education] } \\
\hline \multirow[t]{2}{*}{ Science } & 0.020 & -0.026 & 0.165 \\
\hline & $(0.062)$ & $(0.077)$ & (0.104) \\
\hline \multirow[t]{2}{*}{ Information Technology } & $0.233^{* * *}$ & 0.131 & $0.436^{* * *}$ \\
\hline & $(0.063)$ & (0.109) & $(0.093)$ \\
\hline \multirow[t]{2}{*}{ Engineering } & $0.352 * * *$ & $0.341^{* * *}$ & $0.498 * * *$ \\
\hline & $(0.063)$ & $(0.108)$ & (0.930) \\
\hline \multirow[t]{2}{*}{ Architecture } & 0.147 & 0.123 & 0.249 \\
\hline & $(0.101)$ & $(0.095)$ & (0.169) \\
\hline \multirow[t]{2}{*}{ Agriculture } & 0.022 & -0.035 & 0.185 \\
\hline & $(0.093)$ & (0.111) & (0.146) \\
\hline \multirow[t]{2}{*}{ Medicine } & $0.509 * * *$ & $0.324 * * *$ & $0.799 * * *$ \\
\hline & $(0.082)$ & (0.093) & (0.149) \\
\hline \multirow[t]{2}{*}{ Nursing } & $0.228 * * *$ & $0.193 * * *$ & $0.354 * * *$ \\
\hline & $(0.057)$ & (0.059) & (0.135) \\
\hline \multirow[t]{2}{*}{ Other Health } & $0.210 * * *$ & $0.139^{* *}$ & $0.410^{* * *}$ \\
\hline & $(0.062)$ & $(0.070)$ & $(0.129)$ \\
\hline
\end{tabular}


Table 2 (cont'd) Human Capital Model Estimations to Explain Log (Hourly Wages)

\begin{tabular}{|c|c|c|c|}
\hline Variable & Full Model & Females Only & Males Only \\
\hline \multicolumn{4}{|l|}{ Major Field of Study [Education] } \\
\hline Management & $\begin{array}{l}0.159 * * * \\
(0.044)\end{array}$ & $\begin{array}{c}0.090^{*} \\
(0.052)\end{array}$ & $\begin{array}{l}0.321^{* * *} \\
(0.081)\end{array}$ \\
\hline Law & $\begin{array}{c}0.193 * * \\
(0.093)\end{array}$ & $\begin{array}{l}0.244^{* * *} \\
(0.087)\end{array}$ & $\begin{array}{l}0.243^{*} \\
(0.179)\end{array}$ \\
\hline Society and Culture & $\begin{array}{l}-0.044 \\
(0.048)\end{array}$ & $\begin{array}{l}-0.062 \\
(0.053)\end{array}$ & $\begin{array}{c}0.056 \\
(0.094)\end{array}$ \\
\hline Hospitality & $\begin{array}{l}0.233^{* * *} \\
(0.084)\end{array}$ & $\begin{array}{l}0.340^{* * *} \\
(0.128)\end{array}$ & $\begin{array}{l}0.275^{* * *} \\
(0.089)\end{array}$ \\
\hline Arts & $\begin{array}{c}0.008 \\
(0.071)\end{array}$ & $\begin{array}{l}-0.059 \\
(0.086)\end{array}$ & $\begin{array}{c}0.245^{* *} \\
(0.105)\end{array}$ \\
\hline \multicolumn{4}{|c|}{ Industry of Employment [Education and Training] } \\
\hline Agriculture Industry & $\begin{array}{l}-0.348^{* * *} \\
(0.125)\end{array}$ & $\begin{array}{l}-0.224 \\
(0.350)\end{array}$ & $\begin{array}{l}-0.376^{* * *} \\
(0.128)\end{array}$ \\
\hline Mining & $\begin{array}{c}0.140^{*} \\
(0.079)\end{array}$ & $\begin{array}{c}0.010 \\
(0.120)\end{array}$ & $\begin{array}{r}0.140 \\
(0.092)\end{array}$ \\
\hline Manufacturing & $\begin{array}{c}-0.100 * * \\
(0.046)\end{array}$ & $\begin{array}{l}-0.054 \\
(0.069)\end{array}$ & $\begin{array}{l}-0.147^{* *} \\
(0.059)\end{array}$ \\
\hline Utilities & $\begin{array}{r}0.108 \\
(0.068)\end{array}$ & $\begin{array}{l}0.218^{* * *} \\
(0.070)\end{array}$ & $\begin{array}{l}-0.025 \\
(0.113)\end{array}$ \\
\hline Construction & $\begin{array}{l}-0.047 \\
(0.054)\end{array}$ & $\begin{array}{c}0.032 \\
(0.115)\end{array}$ & $\begin{array}{l}-0.115^{*} \\
(0.066)\end{array}$ \\
\hline Wholesale Trade & $\begin{array}{l}-0.124^{*} \\
(0.056)\end{array}$ & $\begin{array}{l}-0.111 \\
(0.078)\end{array}$ & $\begin{array}{l}-0.160^{* *} \\
(0.074)\end{array}$ \\
\hline Retail Trade & $\begin{array}{l}-0.225^{* * *} \\
(0.063)\end{array}$ & $\begin{array}{l}-0.212^{* *} \\
(0.095)\end{array}$ & $\begin{array}{l}-0.262^{* * *} \\
(0.063)\end{array}$ \\
\hline Hospitality Industry & $\begin{array}{l}-0.193^{* *} \\
(0.076)\end{array}$ & $\begin{array}{l}-0.327^{* * *} \\
(0.102)\end{array}$ & $\begin{array}{l}-0.044 \\
(0.097)\end{array}$ \\
\hline Transport & $\begin{array}{l}-0.107 \\
(0.099)\end{array}$ & $\begin{array}{l}-0.328^{*} \\
(0.188)\end{array}$ & $\begin{array}{l}-0.038 \\
(0.096)\end{array}$ \\
\hline Information Media & $\begin{array}{c}-0.129 * * \\
(0.061)\end{array}$ & $\begin{array}{l}-0.098 \\
(0.078)\end{array}$ & $\begin{array}{l}-0.215^{* *} \\
(0.090)\end{array}$ \\
\hline Finance & $\begin{array}{l}0.175^{* * *} \\
(0.065)\end{array}$ & $\begin{array}{l}0.267^{* *} \\
(0.106)\end{array}$ & $\begin{array}{l}0.0403 \\
(0.072)\end{array}$ \\
\hline Real Estate & $\begin{array}{l}-0.156 \\
(0.103)\end{array}$ & $\begin{array}{l}-0.246 \\
(0.181)\end{array}$ & $\begin{array}{l}-0.059 \\
(0.062)\end{array}$ \\
\hline Professional & $\begin{array}{l}-0.037 \\
(0.037)\end{array}$ & $\begin{array}{l}-0.045 \\
(0.053)\end{array}$ & $\begin{array}{l}-0.073 \\
(0.050)\end{array}$ \\
\hline Administration & $\begin{array}{l}-0.026 \\
(0.034)\end{array}$ & $\begin{array}{c}0.030 \\
(0.047)\end{array}$ & $\begin{array}{l}-0.100^{*} \\
(0.047)\end{array}$ \\
\hline Health & $\begin{array}{l}-0.038 \\
(0.035)\end{array}$ & $\begin{array}{l}-0.033 \\
(0.043)\end{array}$ & $\begin{array}{l}-0.028 \\
(0.065)\end{array}$ \\
\hline Arts and Recreation Services & $\begin{array}{l}-0.212^{* * *} \\
(0.068)\end{array}$ & $\begin{array}{l}-0.194^{*} \\
(0.082)\end{array}$ & $\begin{array}{l}-0.219 * * \\
(0.111)\end{array}$ \\
\hline Other Services & $\begin{array}{l}-0.166^{* * *} \\
(0.055)\end{array}$ & $\begin{array}{l}-0.118^{*} \\
(0.061)\end{array}$ & $\begin{array}{c}-0.222^{* *} \\
(0.101)^{* *}\end{array}$ \\
\hline
\end{tabular}


Table 2 (cont'd) Human Capital Model Estimations to Explain Log (Hourly Wages)

\begin{tabular}{lccc}
\hline \multicolumn{1}{c}{ Variable } & Full Model & Females Only & Males Only \\
\hline \hline Institution Attended [Group of Eight] & & & \\
Australian Technology Group & -0.001 & -0.015 & 0.050 \\
& $(0.037)$ & $(0.044)$ & $(0.061)$ \\
Innovation Research Universities & -0.032 & $-0.103^{*}$ & 0.101 \\
& $(0.040)$ & $(0.050)$ & $(0.066)$ \\
Unaligned Universities & -0.025 & $-0.082^{* *}$ & 0.049 \\
& $(0.031)$ & $(0.036)$ & $(0.052)$ \\
Regional University Network & $-0.113^{* *}$ & $-0.190^{* * *}$ & -0.026 \\
& $(0.057)$ & $(0.069)$ & $(0.093)$ \\
Constant & & & $-0.005^{*}$ \\
& $0.843^{* * *}$ & $1.44^{* * *}$ & $(0.241)$ \\
Overall R2 & $(0.171)$ & $(0.201)$ & \\
Sample Size & & & 0.136 \\
\hline
\end{tabular}

Note: ${ }^{* * *}$ denotes significance at the 1 per cent level; ${ }^{* *}$ denotes significance at the 5 per cent level; * denotes significance at the 10 per cent level; Standard errors in parentheses; [Omitted category in brackets]; (a) = variable not entered. 